at the end of the cell; secondaries, thorax, and abdomen pale shining stramineous; head pure white; antennæ brownish; primaries below and pectus golden or bronzy-greyish without definite markings; venter and secondaries pale shining stramineous. Expanse of wings 19 millim.

Aden (Yerbury and Swinhoe).

Col. Swinhoe's specimen, though recognizable, is a good deal injured by being in spirit.

2. On Lepidoptera collected at Kurrachee. By Lieut.-Col. C. Swinhoe, F.L.S., F.Z.S.

[Received October 4, 1884.]

\title{
(Plates XLVII.-XLVIII.)
}

Kurrachee does not afford a large field for the collection of Lepidoptera ; its main features are sea, sand, and salt soil ; the entire sea-coast of Sind, right up to Soumiani, the ancient seaport of Beloochistan, is a mere reclamation from the sea caused by the scour of the great river Indus, and has, besides babul trees (Acacia arabica), mimosa bushes, and the rank growth peculiar to sea-mud, no vegetation whatever, and even for many miles inland there is little but Babul and Euphorbia-bushes. In some years when rain falls, the grass springs up in the valleys, and some attempt at cultivation is made by the people; but during the time I remained at Kurrachee, from December 1878 up to August 1880, no rain whatever fell, and though I had a trained native collector with me the whole time, who collected regularly every day, the following is but a meagre list compared to what it would be for the same length of time in any other part of India.

The Lepidoptera of Kurrachee are, however, very interesting, more especially with reference to the Teracoli, many different and distinct species from widely ranging localities appearing to meet there.

Heavy rain fell at Kurrachee in the summer of 1882 and I employed a native collector there for some months, through the kind assistance of Mr. Murray, the Curator of the Municipal Museum, who dated and sent me the collections, and these collections contained, as will be seen, several species not observed during the years when no rain fell.

\section{RHOPALOCERA.}

NYMPHAL ID A.

Eupleine.

\section{Tirumala limniace.}

Pap. limniace, Cramer, Pap. Exot. i. pl. 59. f. D, E (1779).

At Kurrachee, in July 1882, after the unusually heavy rain of the summer of that year; is not usually found at Kurrachee or along the 
coast; I did not take a single specimen during the whole of 1879 or

1880. Is common, however, in the interior of Sind.

\section{Salatura genutia.}

Pap. genutia, Cramer, Pap. Exot. iii. pl. 206. f. C, D (1782).

Four sent me by Mr. Murray, the Curator of the Kurrachee Museum, taken on the 28 th of July, and two taken on the 2nd of August; the above note applies also to this species.

\section{Limnas Chrysippus.}

Pap. chrysippus, Linn. Mus. Ulr. p. 263 (1764). Sind.

Common at Kurrachee all the year through, as it is all through

\section{Limnas dorippus.}

Euploea dorippus, Klug, Symb. Phys. pl. 48. f. 1-5 (1845).

Never common at Kurrachee; but an odd specimen was taken by me personally in August, November, and December, 1879, and in January, June, and September, 1880, and one example sent me by Mr. Murray, taken in July 1882. I have no record of it from the interior. The Kurrachee examples show no differences from the few examples in my collection, which were taken in other parts of India -one at Poona, December 1882; one at Kahandalla, October 1882; and two in Bombay, August 1883 ; but they are not identical with my Aden examples, nearly all of which show more or less white on the upper surface of the hind wings, like Klug's type figured in his plate.

\section{Limnas alcippus.}

Pap. alcippus, Cramer, Pap. Exot. ii. pl. 127. f. E, F (1779).

Taken at Kurrachee-one in January 1879, and eleven in November and December, 1882. The white on the hind wings varies much: in some it is hardly sufficient to distinguish it from L. chrysippus.

\section{Melanitis leda.}

\section{SATYRINe.}

Pap. leda, Linn. Syst. Nat. i. 2, p. 773, n. 151 (1767).

One taken by me at Kurrachee; but the date was not recorded.

7. Melanitis ismene.

Pap. ismene, Cramer, Pap. Exot. i. pl. 26. f. A, B (1775). date.

One in the Kurrachee Museum, labelled Kurrachee, but without

Both the above are apparently common in places in the interior (I have specimens of both kinds from Hydrabad); but are apparently very rare on the coast. I observed none at Soumiani, and Mr. Murray failed to send me any from Kurrachee after the heavy rain in 1882 . 


\section{NyMPhaLine.}

8. Atella phalanta.

Pap. phalanta, Drury, Ill. Exot. Ent. i. pl. 21. f. 1, 2 (1773).

Two specimens in July 1882; was not observed throughout $1879-80$.

9. Pyrameis cardui.

Pap. cardui, Linn. Faun. Suec. p. 276, n. 1054 (1761).

Plentiful in several months of the year. I took it in 1879 in January, February, July, August, and December, and in 1880 in June and July.

\section{Junonia Lemonias.}

Pap. lemonias, Linn. Mus. Ulr. p. 277 (1764).

Not observed by me either in 1879 or 1880 ; but the museum has an example said to be taken at Kurrachee.

\section{Junonia hierta.}

Pap. hierta, Fabr. Ent. Syst. Suppl. p. 424 (1798).

Taken by Mr. Murray in July 1882, one example sent me; not observed by me in $1879-80$.

12. JunONiA ORITHYa.

Pap. orithya, Linn. Mus. Ulr. p. 278 (1764).

Appears in April and May, but is not common.

13. Junonia asterie.

Pap. asterie, Linn. Syst. Nat. i. 2, p. 769, n. 133 (1767).

One taken by me in November.

\section{Junonia almana.}

Pap. almana, Linn. Mus. Ulr. p. 272 (1764).

The commonest species of the genus at Kurrachee; appears in January, April, and November.

\section{Hypolimnas bolina.}

Pap. bolina, Linn. Mus. Ulr. p. 295 (1764).

July 1882, two specimens; was not observed throughout 1879-80.

16. Hypolimas misippus.

Pap. misippus, Linn. Mus. Ulr. p. 264 (1764).

Fairly common in the months of August and September. The female mimics Limnas dorippus more commonly than L. chrysippus.

\section{LyCANIDA.}

\section{Polyommatus beticus.}

Pap. baticus, Linn. Syst. Nat. i. 2, p. 789, n. 226 (1767).

Large type appears plentifully in April and May, a few also taken in July. 
18. LAMPIDES KANDARPA.

Lycana kandarpa, Horsfield, Cat. Lep. E. I. C. p. 82, n. 17 (1829).

Kurrachee, July 1882.

19. CAtochrysops CNejus.

Hesperia cnejus, Fabr. Ent. Syst. Suppl. p. 430 (1798).

Large type, plentiful in August and September.

20. Catochrysops contracta.

Lampides contracta, Butler, P.Z.S. 1880, p. 406, pl. xxxiv. f. 3 .

Plentiful in August and September.

I believe this form to be only a seasonal variety of $C$. cnejus; but Mr. A. G. Butler, whose authority is much to be respected, thinks otherwise (P. Z. S. 1880, p. 407). I tried to breed them, but failed.

21. Cатоchrysops ella.

Catochrysops ella, Butler, P. Z. S. 1881, p. 606.

A few specimens taken in December and January.

\section{Tarucus nara.}

Lycæna nara, Kollar, Hüg. Kaschm. iv. 2, p. 421 (1848).

Appears in great plenty at latter end of April and lasts until about the middle of August.

This species appears to be replaced in the north of Sind by the variety Tarucus theophrastus, Fabr., which has all the markings below in distinct and separate spots; all the examples received by me from Sukkur and Shikarpoor being of this type.

\section{Tarucus plinius.}

Hesperia plinius, Fabr. Ent. Syst. iii. 1, p. 284, n. 92 (1793).

Very plentiful in May, June, and July.

\section{Zizera karsandra.} f. 7 .

Polyommatus karsandra, Moore, P.Z. S. 1865, p. 505, pl. xxxi.

The commonest Lycana in Kurrachee. It occurs in great plenty in April and May, a few in August, and then again in countless numbers throughout November and December.

\section{Zizera mora, n. sp. (Plate XLVII. fig. 2.)}

Similar in shape and colour above and below to Z . karsandra, but larger; the markings below are very different and quite distinct. Fore wings with a black spot within the cell and a black mark at the end of the cell, and beyond this a row of six black thick longitudinal streaks between the veins, spear-shaped with the points outside running from near the costa to near the hinder margin, and 
a small longitudinal subcostal streak slightly above and behind this row: hind wings with a subcostal spot one third from the base, a streak within the cell, another adjoining a mark at the end of the cell, and a whorl of streaks outside corresponding to the row on the fore wings - the first streak subcostal, very long, the second a little shorter, the next four less than half the length, and three more mere spots, each lessening in size; all the streaks and spots deep black, , surrounded with white and distinctly separated from each other, giving the outer row of streaks on buth wings the appearance of being stamped on a broad white band. Both wings with a submarginal row of spots slightly darker than the ground-colour of the wings on a greyish ground.

Kurrachee, June 1879, and again taken in June 1882. The Calcutta Museum has also a specimen received from Kurrachee. I thought at first it was merely an aberration of $Z$. karsandra; but as I have taken examples two years runuing, marked exactly similarly, and not at any other period of the year, it is clearly a distinct form.

\section{Zizera PYGMAa.}

Lycena pygmaa, Snellen, Tijdschr. Ent. xix. pl. 7. f. 3 (1876). Appears in July, but is not common.

\section{Chilades putli.}

Lycana putli, Kollar, Hügel's Kaschm. p. 422 (1848).

Muggur Pir, August, common.

28. Azanus zena.

Lycena zena, Moore, P. Z. S. 1865, p. 505, pl. 31. fig. 9. July and August, fairly plentiful.

\section{Aphneus acamas.}

Lyccena acamas, Klug, Symb. Phys. pl. 40. f. 7-9 (1834).

Common in January and February, 1879. Never got another specimen until July of the following year, when it again became very plentiful.

\section{PaPILIONIDE.}

\section{Terias Leeta.}

\section{Pierine.}

T. lata, Boisduval, Sp. Gén. i. p. 674, n. 36 (1836).

One example taken by me at Kurrachee in June 1879; I never procured another anywhere in the neighbourhood. The black border in the fore wings has a peculiar bronzy sheen; otherwise the specimen is identical with examples in my collection from other parts of India.

31. Terias hecabe.

Pap. hecabe, Linn. Mus. Lud. Ulr. p. 249 (1764).

Appears plentifully from April to August.

Proc. Zool. Soc.-1884, No. XXXV. 


\section{Terias hecabeoides.}

Ter. hecabeoides, Mén. Cat. Mus. Petr., Lep. i. p. 85, pl. 2. f. 2 (1855).

Is also fairly plentiful during the summer months. I have specimens of both sexes in my collection, taken at Kurrachee in July and August.

\section{Terias asiope.}

Ter. asiope, Mén. Cat. Mus. Petr., Lep. i. p. 85, pl. 2. f. 3 (1855).

December and January. I took but few examples, however.

\section{Terias curiosa, n. sp. (Plate XLVII. fig. 3.)}

Kurrachee, August 1879.

Shaped like $\boldsymbol{T}$. hecabe, with the peculiar yellow coloration of $T$. venata, Moore. Fore wings-costa black, with a broad black marginal band commencing just outside the middle of the costa, sinuous internally, and filling nearly the whole of the marginal area. Hind wing with the border as in T. hecabeoides. Below quite immaculate.

Expanse of wings $1 \frac{6}{10}$ inch.

\section{Terias purreea.}

Ter. purreea, Moore, P. Z. S. 1882, p. 252.

Is also scarce. I have thirteen in all, taken at Kurrachee in the months of December, January, and February.

\section{Terias asphodelus.}

Terias asphodelus, Butler, P. Z. S. 1883, p. 151, pl. xxiv. f. 13. Three examples in my collection, taken at Kurrachee in February 1880 , exactly correspond with Mr. Butler's description and figure.

\section{Teracolus faustus.}

Pap. fausta, Olivier, Voy. 1. Emp. Oth. Atl. pl. 33. f. 4, $a, b$ (1801).

The common form of this group throughout Sind, extending also throughout Beloochistan and Southern Afghanistan. I have many specimens from Hydrabad, Sukkur, Quetta, and Kandahar. Appears at Kurrachee in January, August, and December.

\section{Teracolus protractus.}

Ter. protractus, Butler, P. Z. S. 1876, p. 137.

Is rare at Kurrachee. I took a few in January and March, 1879. I saw it in great plenty on the Hubb River in August and again in November, and it is very common on the banks of the Indus above Hydrabad. 
39. Teracolus vestalis.

Ter. vestalis, Butler, P. Z. S. 1876 , p. 135, pl. vii. f. 10 ; 1881, p. 609.

Appears in great plenty from April to June.

40. Teracolus puellaris.

Ter. puellaris, Butler, P. Z. S. 1876, p. 136, 1881, p. 609.

Is scarce on the coast, but the common form in the interior. I have numerous specimens from Hydrabad, but at Kurrachee it is to be seen only occasionally in April and May, and again in August and September.

41. Teracolus ochreipennis.

Ter. ochreipennis, Butler, P. Z. S. 1876, p. 136, 1881, p. 609.

Plentiful in December. T. intermissus is but a slight and not at all constant variety of $T$. ochreipennis.

42. Teracolus peelus.

Teracolus peelus, C. Swinhoe, P.Z.S. 1884, p. 439, pl.xxxix. fig. 9.

Kurrachee, May and September.

43. Teracolus dubius.

T. dubius, C. Swinh. P. Z. S. 1884, p. 439.

Kurrachee, July, August, and September.

44. Teracolus dynamene.

Pontia dynamene, Klug, Symb. Phys. pl. 6. f. 15, 16 (1829).

From April to December, very common.

45. Teracolus Carnifer.

Ter. carnifer, Butler, P. Z. S. 1876, p. 138, pl. vii. f. 8, 9.

November and December, common.

46. Teracolus dulcis.

T. dulcis, Butler, P. Z. S. 1876 , p. 157 , pl. vii. f. 13.

T. dirus, Butler, l. c. fig. 11.

T. eboreoides, Butler, l. c. p. 158, pl. vii. f. 12.

T. phoenius, Butler, Ann. Nat. Hist. (4) xviii. p. 488 (1876).

Kurrachee, very common from April to August.

The types of T. dulcis came from Kattywar and North India, and Mr. Butler at the same time refers to a variety of both sexes from Sind.

The type of $T$. dirus came from Sind, being described as a female example. The types of both sexes of $T$. eboreoides are merely marked India (W. B. Farr). The types of T. phonius came from Abyssinia.

I collected regularly every day at Kurrachee for a year and nine months, until the middle of August 1880, when I went up to 
Kandahar, carefully recording captures each day ; and in separating species I found that, although all four of these forms seemed to be common at Kurrachee, I had still a number of examples that seemed to belong to none of them, and yet were closely allied to each.

On my return from field service, when passing through Kurrachee, I engaged a man to collect for me from April to August 1883, and Mr. Murray, the Curator of the Kurrachee Museum, very kindly agreed to have the collections brought to him daily for labelling.

The result is that, after setting out some hundreds of examples, I can show a perfect series from $T$. phoenius (of Sind) to $T$. dulcis. The normal form, I believe, must have been $T$. phoenius. It is beautifully and clearly marked, and is quite distinct from all the other species of the $T$. danae group. But as $T$. dulcis was first named, $T$. phoenius, as well as $T$. dirus and $T$. eboreoides, must sink into synonyms.

The types of all four forms, when taken separately, appear to be quite distinct; but from examination of my long series captured in the same months of the year at the same place, I think I have satisfied Mr. Butler that all are of the same species.

Similar variations, it will be seen, occur in the $T$. etrida group, also in the $T$. eucharis group, from Bombay and Southern India generally; and it is worthy of remark that, although the variations seem to occur commonly in the group Callosune, the whole of the subgenus Idmais appears to be remarkably constant in all the yet known species.

\section{Teracolus immaculatus.}

Teracolus immaculatus, C. Swinhoe, P. Z. S. 1884, p. 443.

Kurrachee, August.

This is, I am inclined to think, only a spotless variety of $T$. dulcis.

\section{Teracolus subroseus.} 6,7 .

Ter. subroseus, C. Swinhoe, P. Z. S. 1884, p. 443, pl. xl. figs.

Kurrachee, July and August.

A perfectly distinct and pretty species.

\section{Teracolus etrida.}

Anthocaris etrida, Boisduval, Sp. Gén. Lép. i. p. 576 (1836). 15.

Ter. purus, Butler, P. Z. S. 1876 , p. 160, n. 113, pl. vii. f. 14,

Kurrachee, April to July, very common.

Examples vary much in size and in markings and general coloration. The hind wings of some of the males are almost immaculate, and many of the females are without the discal markings of the type; but, as in the T.-dulcis group, the number of intermediates found on an examination of a very large series makes it impossible to separate them. 
50. Teracolus limbatus.

Ter. limbatus, Butler, P. Z. S. 1876, p. 161.

Kurrachee, June 1880. One male example.

The deep brown, rather broad, sinuated band on the secondaries distinguishes this species from all the others in the group of orangetips. But I am of opinion it is only an aberrant form of the foregoing.

\section{Teracolus bimbura.}

Ter. bimbura, Moore, P. Z. S. 1876, p. 161, pl, vii. f. 3, 4.

Kurrachee, December, January, and February.

52. Teracolus pernotatus.

Ter. pernotatus, Butler, P. Z. S. 1876, p. 159, pl. vii. f. 1 .

T. farrinus, Butler, P. Z. S. 1876, p. 159, pl. vii. f. 2.

Kurrachee, July, August, and September.

These cannot be separated, although there are perfectly typical forms of each. The intermediates found on an examination of a long series must convince any one that they are identical.

\section{Pieris mesentina.}

Pap. mesentina, Cramer, Pap. Exot. iii. pl. 270. f. A, B (1782).

The pale type appears plentiful from February to May.

54. Pieris zeuxippe.

Pap. zeuxippe, Cramer, Pap. Exot. iv. pl. 362. f. E, F (1782).

One specimen taken by me in 1879 , but the date was not recorded.

55. Catopsilia pyranthe.

Pap. pyranthe, Linn. Mus. Ulr. p. 245 (1764).

A few specimens taken in March, May, June, and December.

56. Catopsilia thisorella.

Callidryas thisorella, Bois. Sp. Gén. i. p. 609, n. 3 (1836).

March to May, common.

57. Catopsilia philippina.

Pap. philippina, Cramer, Pap. Ex. iv. pl. 361. f. C, D (1782).

September to January, common.

58. Catopsilia crocale.

Pap. crocale, Cramer, Pap. Exot. i. pl. 55. f. C, D (1779).

I took one female in Kurrachee in 1879 , now in my collection, date not recorded. I have received another, also a female, from Mr. Murray, taken by him in July 1882 . 


\section{Papilionine.}

59. Papilio (Menelaides) diphilus.

Pap. diphilus, Esper, Ausl. Schmett. pl. 40 B. f. 1 (1785-98).

Kurrachee, July and August, plentiful.

60. Papilio (Laertias) pammon.

Pap. pammon, Linn. Mus. Ulr. p. 189 (1764).

One pair in the Municipal Museum, said to have been taken at Kurrachee. The female of $\boldsymbol{P}$. diphilus pattern not observed in Kurrachee by me.

61. Papilio (Opheides) erithonius.

Pap. erithonius, Cram. Pap. Exot. iii. pl. 232. f. A, B (1782).

Kurrachee, common all the year through.

\section{Ismene ALexis.}

\section{Hesperide.}

Pap. alexis, Fabr. Syst. Ent. p. 533, n. 387 (1775).

Kurrachee, July 1882, one example taken; one also received from Hydrabad.

\section{Ismene Chromus.}

Pap. chromus, Cramer, Pap. Exot. iii. pl. 284. f. E (1782).

One example received from Hydrabad.

64. Pamphila mathias.

Hesperia mathias, Fabr. Ent. Syst. Suppl. p. 433 (1798).

Kurrachee, common at all seasons.

65. Pamphila bevani, Moore.

Hesperia bevani, Moore, P. Z. S. 1878, p. 688.

Seven examples received from Mr. Murray, taken at Kurrachee in July 1882 .

66. Pamphila karsana.

Hesperia karsana, Moore, P. Z. S. 1874, p. 576, pl. 67 . f. 6 .

A common species at Kurrachee at all seasons of the year.

67. SARANGESA PURENDRA.

Pyrgus purendra, Moore, Cat. Lep. Mus. E. I. C. i. p. 250.

One example received from Hydrabad.

68. Pyrgus galba.

Hesperia galba, Fabr. Ent. Syst. iii. 1, p. 352, n. 337 (1793).

Kurrachee, June to October, common.

69. Pyrgus evanidus.

Pyrgus evanidus, Butler, Ann. \& Mag. Nat. Hist. March 1880, p. 223.

Kurrachee, January, February, and March, common. 


\section{Gomalia litoralis, n. sp. (Plate XLVII. fig. 4.)}

Kurrachee, July 1879, in the salt-marshes on the sea-shore.

Allied to G. albofasciata, Moore. Larger, and more marked with white above; costa arched, very nearly straight; ground-colour similar. Fore wing with a deep short white band occupying the space at the end of the cell, marked with black on the inner side, the black colour continued in the form of a band to the hinder margin, forming an elbow at the larger end of the white band; a black band near the base, edged with whitish; a lunular white spot on the disk, with a small white spot near it above; a white streak running down from the costa near the apex; costa greyish; fringe of the wing alternate brown and grey. Hind wings with a white spot at the base, a broad white discal band, and a deep white sinuous fringe. Below, the indications of the white markings are similar, but there is a white band at the base of the hind wings instead of a spot, and the entire surface of both wings is of a suffused pale bronzy-brown colour, with all the markings suffused and indistinct.

\section{HETEROCERA.}

\section{SPHINGIDA.}

1. Acherontia styx, Westwood, Cab. Orient. Ent. p. 88, pl. 42 . f. 3 .

Kurrachee, July and August.

Larvæ feed on potato, jasmine, colia, Erythrina indica and Datura. Colour varies in accordance with the kind of food they are found on: those feeding on potato were of a bright canary-yellow, with seven violet stripes, those on jasmine were of a darker colour, and those found on $E$. indica and Datura were green with purple stripes. All produced the same kind of moth, without any visible difference in the shade of colouring or markings; the larvæ and moths both make the same peculiar clicking noise when disturbed. Length 4 to $5 \frac{1}{2}$ inches. Larval stage 28 days; pupal stage varies from 1 to 4 months.

2. Da phnis nerit, Linn. Syst. Nat. i. 2, p. 798, no. 5.

Kurrachee, March, April, and May (1879-80).

Reared by me two years in succession (1879-80); larvæ feed on leaves of wild oleander and on flowers of the cultivated double garden oleander, not touching the leaves of this kind; has three broods in succession. I have also found the larva at Poona on Tabernamontana and Coronaria; the coloration of the moths at Poona is, however, much darker.

3. Deilephila livornica, Hübner, Sphing. p. 96, no. 5, pl. 12. f. 65 , pl. 23 . f. 112 .

Kurrachee, March and May (1879-80).

4. Cherocampa Celerio, Linn. Syst. Nat. i. 2, p. 800, no. 12. Kurrachee, November and December.

Larvæ feed on Caladium; there are three or four broods in suc- 
cession : in Poona the first lot of larvæ in June, in the height of the monsoon rains, became pupæ in 14 or 15 days, and only remained in the larval stage 10 days ; but the last lot in September were much more delicate and slower in growth. They fed for a month, and the perfect insect did not emerge until the following June, with the commencement of the monsoon rains.

f. 1 .

5. Cherocampa nessus, Drury, Ill. Exot. Ins. ii. p. 46, pl. 27.

One fine example taken at Kurrachee, October 1879.

6. Chळrocampa elpenor (Linn.), Faun. Suec. p. 288, no. 1089. One example received from the Municipal Museum, taken at Kurrachee, date not noted; it appears to me identical with the British type.

7. Cherocampa oldenlandie, Fabr. Sp. Ins. ii.p. 148, no. 37. Kurrachee, December (1879-80).

8. Macroglossa stellatarum (Linn.).

Kurrachee, July 1879 , one example only taken. It is very plentiful in Beloochistan and Southern Afghanistan.

9. Cephanodes hylas, Linn. Mant. i. p. 539.

Kurrachee, common in December.

\section{ZYGENIDE.}

10. Euchromia polymena, Linn. Syst. Nat. ii. p. 806, no. 40. Several examples received by me in a collection made at Kurrachee in 1882 by Mr. Murray, but no date was recorded.

\section{Agaristide.} f. D.

11. Agocera venulia, Cramer, Pap. Exot. ii. p. 107, pl. 165.

Kurrachee, July 1882.

\section{LITHOSIIDE.}

12. Deiopeia Pulchella, Linn. Syst. Nat. i. 2, p. 804, no. 349.

A variety was very plentiful at Kurrachee from January to May; typical $D$. pulchella appears in October and November (1879-80), but is not nearly so plentiful.

Var. Lotrix, Cramer, Pap. Exot. ii. p. 20, pl. 109. f. E.

I took many examples of this form in the Hubb River, in the borders of Beloochistan, within 25 miles of Kurrachee, in November 1879 , in company with typical $D$. pulchella, and received examples also from Kotree, North Sind, taken in March 1880. 
Var. THYTER, Butler, Trans. Ent. Soc. 1877, p. 361.

Examples of this variety were taken in the Hubb by me in November 1879 ; and in the month following in company with the above; it is the common form in Beloochistan and Southern Afghanistan. I got many examples in the Bolan in June, at Quetta in May and September, and one example at Kandahar in November 1880. Types of all these varieties have been examined and identified by Mr. A. G. Butler.

\section{LIPARIDE.}

13. Artaxa pygman, Moore, Pub. Asiat. Soc. Bengal, Atkinson Col. p. 48 ; P.Z.S. 1883 , p. 156.

Kurrachee, February 1880, May, July 1879. Common.

14. Gomena subnotata, Walker, Cat. Lep. Het. B. M. xxxii, p. 502.

Kurrachee, February 1880, August, November 1879.

\section{LASIOCAMPIDE.}

\section{Taragama ganesa, Lefebvre.}

Taragama ganesa, Lefebvre, Zool. Journ. iii. p. 211 (1827); Moore, Cat. Col. E. I. M. ii. p. 427.

Kurrachee, May and September (1879-80).

Larva $3 \frac{1}{4}$ inches long, hairy, with down quite close to the skin; colour grey; feeds on Acacia arabica. They are night-feeders, hiding during the day in the crevices of the bark. Larval stage 50 to 56 days; pupal stage 21 to 24 days. Spins in a twig of any small plant near foot of the food-tree, or on a neighbouring wall; I have found many cocoons, but never one on the food-tree.

\section{Cossida.}

16. Brachylia ACronyctoides, Moore, P. Z. S. 1879, p. 411 , pl. 34 . f. 4.

Kurrachee, May.

\section{NotodonTIDE.}

17. Thiacides postica, Walker, Cat. Lep. Het. B. M. v. p. 1028. Kurrachee, May and September 1879.

18. Phragmatecia Fedd, n. sp. (Plate XLVII. fig. 1.)

Kurrachee, January and February.

Colour ashy grey; thorax and abdomen covered with long grey hairs, the latter conical, extending far beyond the wings. Antennæ of the male moderately pectinated throughout, of the female simple. Fore wings with a reddish testaceous band along the costa, extending along the outer border and inner margin, making a complete circle of the wing, and a band of the same colour from the base ex- 
tending under, and up to the end of the discoidal cell, and then continuing upwards to the costa near the apex. Hind wings immaculate. Expanse of wings, of $\frac{91}{10}$, ㅇ $1 \frac{4}{10}$ inches.

\section{NoCTUж.}

\section{LeUCANIIDE.}

19. Leucania Loreyi, Duponchel, Hist. Nat. Lép. Fr. iv. p. 81, pl. 105. f. 7.

Kurrachee, February, April, May (1879-80). Common.

\section{Apaminde.}

20. Ilattia cephusalis, Walker, Cat. Lep. Het. B. M. xvi. p. 209.

Kurrachee, November (1879-80).

21. Laphygma exigua, Hübner, Samml. eur. Schmett., Noct. f. 362 .

Kurrachee, June.

\section{Noctuide.}

22. Agrotis aristifera, Guénée, Noct. i. p. 266, no. 426.

Kurrachee, February (1879-80). Common.

23. Caradrina sabulosa, n. sp. (Plate XlVII. fig. 6.)

Kurrachee, May 1879.

Fore wings pale greyish ochreous, markings brown, with two basal spots, one on the costa, a strigula near the base; one antemedial, one postmedial (with a spot in the costa between them), a suffused strigula before the apex, orbicular and reniform spots speckled and indistinct; a distinct small ringlet below the orbicular spot, and a much larger one in the upper part of the disk; a brown shade in the basal half of the hinder margin, a sinuous line on the outer margin, with minute white spots on the veins, and the brown line running partly inwards, on the veins ; fringe brownish. Hind wings silvery white, with a suffused brown border; fringe silvery white. Underside silvery white, fore wings with brownish centre and outer border ; hind wings with brownish border. Expanse of wings 1 inch.

24. Caradrina venosa, Butler, Ent. Month. Mag. vol. xvii. p. 7 (1880).

Kurrachee, November.

25. Caradrina insignata, Walker, Cat. Lep. Het. B. M. x. p. 295.

Kurrachee, June, May, July, and November.

26. Spelotis undulans, Moore, Sci. Res. Yark. Miss., Lep. pl. 1. f. 10 (1876); P. Z.S. 1881, p. 617.

Kurrachee, November. 


\section{Orthosinde.}

27. Orthosia Infrequens, $\mathrm{n}$. $\mathrm{sp}$. (Plate XLVII. fig. 11.)

Kurrachee, July.

Dull fawn-colour: fore wings with the outer border slightly toothed; orbicular and reniform spots distinct, with greyish rings; a deep outer border darker than the ground-colour, with the veins showing lighter; hind wings paler than the fore wings, with a gloss on them; outer border as in the fore wings. Expanse of wings $1 \frac{2}{1 \sigma}$ inch.

\section{XYLINIDE.}

28. Jarasana lativitta, Moore, Desc. Lep. in Atkinson Col., vol. ii. p. 132.

Kurrachee, July $1879 . \quad$ One example.

\section{ACONTIIDe.}

29. Xanthodes innocens, Walker, Cat. Lep. Het. B. M. xv. p. 1752 .

Kurrachee, October and November, 1879 and 1880.

30. Xanthodes arcuata, Walker, Cat. Lep. Het. B. M. xii. p. 779 .

Kurrachee, February.

31. Acontia hortensis, n. sp. (Plate XLVII. fig. 7.)

Kurrachee, September.

Allied to A. solaris of Europe, but considerably smaller. Fore wings chocolate-brown, speckled with white at the base; a broad white band before the middle; a large square white spot on the costa before the apex; a sinuous submarginal white line, the margin also marked with white. Hind wings pale chocolate-colour, with the border slightly darker. Underside very pale bronzy chocolate, with the white markings showing through. Expanse of wings $\frac{9}{1} \sigma$ inch.

\section{Erastria futilis, n. sp. (Plate XLVII. fig. 8.)}

Kurrachee, March.

Allied to E. scitula. Silvery grey; palpi and eyes black: fore wings with a basal and antemedial line brown, the latter bordered with grey outwardly, beyond this the whole of the wing is more or less blackish brown, with the reniform stigma black, and with a postmedial and submarginal wavy white line, both expanding towards the costa, making the apical portion of the wing whitish ; marginal line black. Hind wing with the lower part of the basal third suffused with brownish, with a brownish diffused discal band, and with some brownish in the margin; marginal line black. Expanse of wings $\frac{6}{10}$ inch. 


\section{HELIOTHID正.}

33. Heliothis armigera, Hübner, Noct. pl. 79. f. 370 .

Kurrachee, in great numbers in January 1879-1880.

Var. Peltigera, Denis, Wien, Verz. p. 89, n. 2; Walker, xi. p. 683 .

Kurrachee, July 1882 . One example.

This is the common form across the Hubb River in Beloochistan. I also found it in great numbers at Ispingil in June, and at Quetta in September.

34. Adisura leucanioides, Moore, P. Z. S. 1881, p. 368.

Muggur Pir, 18 miles from Kurrachee, August 1880.

\section{Anthophilide.}

35. Acantholipes affinis, Butler, Ann. \& Mag. Nat. Hist. ser. 5, vol. v. p. 225 (1880).

Kurrachee, February, May, November, and December, 1879, 1880. Very plentiful.

36. Anthophila zamia, n. sp.

Kurrachee, April.

Thorax and fore wings pinkish cinereous; body paler ; fore wings with a central and an outer wavy white line, the latter bordered with blackish on the inner side, and the space between that and the central line paler than the rest of the wing; marginal line brown; fringe interlined-brown, white, and brown. Hind wings pinkish white, with a discal sinuous white line, a marginal double brown line, and cilia as in fore wings. Expanse of wings 1 inch.

\section{Anthophila bulla, n. sp. (Plate XLVII. fig. 9.)}

Kurrachee, January.

Pale greenish grey; head and sides of thorax white; a black spot on the fore part of the thorax; costa of fore wings and the veins dark, otherwise the wings are unmarked. Expanse of wings $\frac{6}{10}$ inch.

38. Micra derogata, Walker, Cat. Lep. Het. B. M. xii. p. 825. Hubb River, August.

39. Micra chalybea, n. sp. (Plate XLVII. fig. 10.)

Kurrachee, January.

Colour steel-grey ; costa greenish grey ; a medial slightly sinuous white line on the fore wing, bounded by a greenish-grey band on the inner side; outer third suffused with greenish grey, with some subapical marks, and a marginal line of a deeper colour; fringe greenish grey. Hind wing pale steel grey, slightly darker towards the border, with a dark marginal line; fringe grey. Expanse of wings $\frac{6}{10}$ inch. 
40. Micra furia, n. sp. (Plate XLVII. fig. 13.)

Kurrachee, September.

Brownish grey; apex of wings very acute ; outer border straight, oblique, veins prominent, otherwise the wings are unmarked. Expanse of wings $\frac{6}{10}$ inch.

41. Micra balux, n. sp. (Plate XlVII. fig. 14.)

Kurrachee, April and August.

Bright golden brown; head pale pinkish; wings and body quite unmarked. Expanse of wings $\frac{6}{10}$ inch.

\section{Plusima.}

42. Plusia verticillata, Guénée, Noct. ii. p. 344, no. 1168.

Kurrachee, January, February, and November, 1879-1880. Very plentiful.

43. Plusia extrahens, Walker, Cat. Lep. Het. B. M. xii. p. 929 .

Kurrachee, March and July, 1879-1880.

\section{CALPide.}

44. Oresia vagabunda, n. sp. (Plate XLVIJ. fig. 5.)

Kurrachee, May.

Reddish cinereous ; antennæ of the male pectinated for two thirds of its length, of the female simple; abdomen pale ochreous cinereous : fore wings with a central diffused brownish-red band, which is retracted towards and stops short of the costa; an outer wavy band of the same colour from two thirds of the hinder margin up to the apex, margined with ochreous cinereous in the outer side, the whole surface of the wing dotted with brown atoms of various sizes. The female is paler than the male, and has all the veins marked with brown at the outer margin; hind wings of the male white, slightly suffused with pinkish ochreous towards the outer margin; in the female the hind wing is of a pale reddish-cinereous colour, slightly darker at the outer margin. Expanse of wings, of 1, 아 $1 \frac{2}{10}$ inch.

\section{Gonopterida.}

45. Gonitis involuta, Walker, Cat. Lep. Het. B. M. xiii. p. 1003.

Kurrachee, June 1879-1880. Common.

Polydesmide.

46. Pandesma fugitiva, Walker, Cat. Lep. Het. B. M. xiv。 p. 1365.

Kurrachee, March to September, 1879-1880. The commonest moth in Kurrachee. 
47. Pandesma similata, Moore, P. Z. S. 1883, p. 24.

Shikapore, April 1879.

Two chrysalides received by post, hatched two days after arrival, producing one of each sex.

48. Pandesma devia, n. sp. (Plate XLVIII. fig. 3.)

Kurrachee, June.

In coloration and markings it has the general appearance of a large Heliothis armigera. Body whitish grey : fore wings ochreous ash colour; costa with a few brown marks near the base, a small orbicular ringlet; reniform stigma large, excavated anteriorly; an inner and an outer latitudinal thin slightly sinuous line, a broad grey band right across the marginal area, suffused inwardly and bordered with a sinuous white line outwardly, with a black spot on this line towards the apex of the wing, with brown lines on the veins extending from this white line to the outer border; fringe brown. Hind wings pale ochreous grey, with a very broad, brown discal band, and a somewhat suffused lighter brown marginal border ; fringe white. Underside pale whitish grey, slightly brown on the borders and costa, with a pale brown discal band through both wings. Expanse of wings $1 \frac{8}{10}$ inch.

\section{HOMOPTERIDA.}

49. Номоptera vetusta, Walker, Cat. Lep. Het. B. M. xxxiii. p. 875 .

Kurrachee, April and May, 1879-1880. Common.

\section{HYPOGRAMMIDE.}

50. SELEPA Docilis, Butler, P. Z.S. 1881, p. 619.

Kurrachee, May and November, 1879-1880. Hubb River, November 1879 .

\section{Othora anea, n. sp. (Plate XLVIII. fig. 1.)}

Kurrachee, July.

Aneous brown, paler beneath and more bronzy ; fore wings above with a basal wavy band which stops short of the costa, and a central wavy band which passes across the reniform stigma, of a darker colour; otherwise both wings above and below are unmarked. Expanse of wings 1 inch.

\section{BENDIDE.}

52. Hamodes aurantica, Guénée, Noct. iii. p. 203, no. 1603. Jacobabad, January 1879.

\section{Ophiusida.}

53. Lagoptera magica, Hübner, Samml. exot. Schmett. iii. ॰p. 32 , no. 268 , f. 535,536 .

Kurrachee.

Is not uncommon; but unfortunately I have no note of dates. I have found the larvæ feeding on Quisqualis indica. 
54. Ophiodes Seperans, Walker, Cat. Lep. Het. xiv. p. 1357.

Kurrachee.

I took one example in my house in 1879 , but the date is not recorded; the larva of this species was also found feeding on Quisqualis indica in Poona, where it is quite common.

55. Ophiodes tumidilinea, Walker, Cat. Lep. Het. xiv. p. 1433.

Kurrachee; no date recorded.

56. Aсhea melicerte, Drury, Ins. i. p. 46, pl. 23. f. 1.

Was very common in July 1882, after the heavy rain, and I received a number from $\mathrm{Mr}$. Murray. I did not, however, find any in either 1879 or 1880 . The larvæ feed on Ricinus communis. I also brought up some in Bombay on wild cucumber. Length $2 \frac{1}{4}$ to $2 \frac{1}{2}$ inches; colour varies, some are deep purplish black, some reddish, some orange-tinted; larval stage 21 to 24 days; pupal stage 18 to 21 days.

57. Grammodes ammonia, Cramer, Pap. Exot. iii. p. 98, pl. 250. f. D.

Common in July.

58. Grammodes stolida, Fabr. Sp. Ins. ii. p. 218, no. 54.

Common in June and July; in great abundance again in November.

59. Ophiusa albivitta, Guénée, Noct. iii. p. 271, no. 1707.

Was common in Kurrachee in the summer of 1879 , but I have no record of dates.

60. Trigonodes hippasia, Cramer, Pap. Exot. iii. p. 99, 250.f. E.

Very common. I took it in June and in September and October.

REMigIDE.

61. Remigia frugalis, Fabr. Ent. Syst. iii. 2, p. 138.

A few taken in August; common in October and November.

62. Remigia archesia, Cramer, Pap. Exot. iii. p. 145, pl. 273. f. F, G.

Was not observed during $1879-80$, but appeared in great abundance after the rain in July 1882 .

63. Remigia arefacta, n. sp. (Plate XLVIII. fig. 2.)

Kurrachee, May.

Allied to $R$. multilinea and also to $R$. hansalii. Palpi pubescent, third joint lanceolate, much longer than the second, ascending; antennæ slender; abdomen whitish cinereous; thorax and general colour of both wings ochreous ashy, irrorated with ochreous brown; 
an ochreous-brown band running through the disk of both wings, from the costa near the apex of the fore wings to the anal angle of the hind wings ; outer portion of wings clouded with dusky ochreous, a marginal sinuous brown line, with brown points; fringe broad, interlined in five parts, whitish and brown alternately. Expanse of wings $1 \frac{1}{10}$ inch.

\section{Thermesinde.}

64. Azazia rubricans, Boisd. Faun. Lép. Mad. p. 106, no. 11, pl. 16. f. 1 .

Common in November in company with a very dark, nearly black variety.

\section{HERMINIIDE.}

65. Rivula sericealis, Denis, Wien. Verz. p. 122, n. 18.

Common throughout the year.

66. Rivula flavonigra, n. sp. (Plate XLVII. fig. 15.)

Kurrachee, March.

Head, antennæ, fore part of the thorax, and outer three fourths of the fore wings black ; remainder of the thorax, abdomen, and basal portion of the fore wings (except the costa, which is also black) dull yellow ; segments of the abdomen washed with pale brown; anal tuft ochreous; all the yellow parts more or less marked with black : fore wings with three spots on the costa near the apex, the marginal points " reniform," marked thus $\mathrm{Il}$, the orbicular double dots, and many minute atoms all over the black portion of the wing, yellow; fringe black: hind wings white, pale brownish towards the border, marginal line brown, fringe white. Expanse of wings $\frac{5_{2}^{\frac{1}{2}}}{10}$ inch.

67. Byturna digramma, Walker, Cat. Lep. Het. B. M. xxxiv. p. 1170 .

Kurrachee, June.

68. Marimatha lactea, n. sp. (Piate XlViII. fig. 7.)

Kurrachee, May.

Glossy yellowish cream-colour, abdomen and hind wings paler, fore wings with black points, otherwise quite unmarked.

Expanse of wings $\frac{9}{10} \mathrm{inch}$.

69. Myana sopora, n. sp. (Plate XLVIII. fig. 4.)

Kurrachee, January and March.

Ochreous cinereous, irrorated with brown, costa with brown marks, reniform mark brown, lunular, a pale greyish suffused central band, a submarginal band blackish towards the apex, and a macular marginal band pale greyish, with black points on the veins between; fringe ochreous grey, with pale ochreous-brown border. Hind wings with the general pattern like the fore wings, but more indistinct. Thorax with a pale greyish-brown band in front. Expanse of wings ] inch. 


\section{Myana atromacula, n. sp. (Plate XLVIII. fig. 5.)}

Kurrachee, February.

Ochreous cinereous; thorax with a brownish band in front; fore wings - costa brownish with black dots, outer third brownish suffused inwardly, with black marginal points, and black on the veins; a large reniform black spot, and two large deep black longitudinal streaks near the base, a wavy double ill-defined outer line. Hind wings same general colour as the fore wings, with a discal suffused brownish band. Expanse of wings 1 inch.

\section{Pyrales. \\ Pyralide.}

71. Hypotia vulgaris, Butler, P.Z.S. 1881, p. 621.

Common from March to May and from August to November.

72. Нyротia vafera, n. sp. (Plate XLVIII. fig. 8.)

Kurrachee, April.

Allied to the preceding. General colour pale chocolate-grey; abdomen paler, with each segment distinctly marked with silvery grey : fore wings with the basal third pale chocolate, bounded outwardly with a darker, slightly waved line, succeeded by a white band; a dark chocolate band beyond the middle, running from the centre of the hinder margin to the costa near the apex, the central space between these bands much paler than the rest of the wing; outer third of the wing same colour as the basal third, with a white deeply waved band joining the last band at the costa ; a chocolate spot at the end of the cell : hind wings whitish, with a deep diffused, pale greyish-chocolate border, with a wavy white band running through it ; fringe whitish, with chocolate edges. Expanse of wings $\frac{9 \frac{1}{2}}{10}$ inch.

\section{Hypotia rubella, n. sp. (Plate XlVIII. fig. 9.)}

Kurrachee, January and August.

Body and basal third of fore wings chocolate-grey ; rest of the wing very much paler, nearly white; two white lines-one bordering the basal third, edged inwardly with brown, and nearly straight, the other very wavy, commencing at the costa near the apex, and terminating at the centre of the hinder margin, and edged with brown outwardly; some darker shades of colour near this line; marginal line white with black spots; fringe white. Hind wings greyish white, with a thin brown marginal line; fringe white. Expanse of wings $\frac{7}{10}$ inch.

74. Pyralis gerontesalis, Walker, Cat. Lep. Het. B. M. xix. p. 896 .

Kurrachee, January.

75. Pyralis uberalis, n. sp. (Plate XlViII. fig. 10.)

Kurrachee, May.

Fore wings and thorax greyish brown striated with white; head Proc. Zool. Soc.-1884, No. XXXVI. 
white ; a white line across the thorax in front ; abdomen whitish ; legs pure white: fore wings with two white marks at the base, a curved white line from the costa near the base to the centre of the hinder margin; three white lines all running inwards from the apex-one curved, near the costa, nearly joining the last-mentioned line, one submarginal and straight, and one slightly sinuous and close to the submarginal line, terminating on the outer two thirds of the hinder margin ; marginal line greyish brown, double ; fringe grey, margined with greyish brown. Hind wings white, slightly coloured towards the margin, with a double greyish-brown marginal line; fringe pure white. Expanse of wings $\frac{6}{10}$ inch.

Asopinde.

f. 0 .

76. Hymenia fascialis, Cramer, Pap. Exot. iv. p. 236, pl. 398.

Common from June to August.

77. Leucinodes orbonalis, Guénée, Delt. et Pyral. p. 223, n. 187 .

Larkana, July.

\section{SteniIDe.}

78. Diasemia geometralis, Guénée, Delt. et Pyral. p. 278 (1854).

Common in December.

\section{Hydroca MPID}

79. Hydrocampa tenera, Butler, P. Z. S. 1883, p. 167.

Kurrachee, January and May.

80. Oligostigma incommoda?, Butler, P. Z. S. 1881 , p. 180. Kurrachee, November.

81. Paraponyx affinialis, Guénée, Delt. et Pyral.p. 270, n. 279. Kurrachee, May.

\section{Hercynide.}

82. Aporodes meleagrisalis, Walker, Cat. Lep. Het. B. M. xvii. p. 324 .

Common from February to April.

\section{SPilomelide.}

83. Zebronia aurolinealis, Walker, Cat. Lep. Het. B. M. xvii. p. 478 .

July and August.

\section{Margarodide.}

84. Pygospila tyres, Cramer, Pap. Exot. iii. p. 124, pl. 263. f. C.

One example taken at Kurrachee in 1879 , date not recorded. 
85. Phakellura indica, Saunders, Zool. ix. p. 3070.

Very common in July and August.

86. Glyphodes univocalis, Walker, Cat. Lep. Het. B. M. xvii. p. 499.

Common in November and December.

BotIDIDE.

87. Godara comalis, Guénée, Delt. et Pyral. p. 369 (1854).

Common at Kurrachee in January, May, and December; also taken at Muggur Pir in August.

88. Godara incomalis, Guénée, Delt. et Pyral. p. 369 (1854).

Kurrachee, May and December.

89. Scopula palmalis, n. sp. (Plate XLVIII. fig. 11.)

Kurrachee, November.

Allied to S. massalis. Silver-grey ; head, palpi, antennæ, and fore part of the thorax chestnut-red : fore wings with the costa, spot at the end of the cell, a number of marks near the base, and the outer third of the wing chestnut-red ; a silver-grey discal line and a brown marginal line ; fringe chestnut-red : hind wings silver-grey, suffused with reddish, a discal chestuut band, some reddish on the outer border, and a macular chestnut marginal line; fringe white. Expanse of wings $\frac{7}{10}$ inch.

90. Nymphula interpunctalis, Hübner, Pyral. ii. p. 19, fig. 128.

Kurrachee, May to July. Muggur Pir, August.

91. Ebulea catalaunalis, Duponchel, Lép. de France, viii. p. 330 , pl. 232 . f. 8 .

Kurrachee, May.

92. Botys ispasalis, Walker, Cat. Lep. Het. B. M. xviii. p. 652 .

Common from May to September.

93. Botys abstrusalis, Walker, Cat. Lep. Het. B. M. xviii. p. 663 .

Kurrachee, April, July, and November.

94. Botys edipodalis?, Walker, Cat. Lep. Het. B. M. xviii. p. 569.

Kurrachee, December.

\section{SCOPARIIDE.}

95. Stenopteryx hybridalis, Hübner, Pyral.pl. 17. f. 114. January, February, May, and November. Very common. 
96. Scotomera tristis, Butler, P.Z. S. 1881, p. 623.

Kurrachee, March. Hubb River, November.

Pterophoride.

97. Pterophorus congrualis, Walker, Cat. Lep. Het. B. M. xxx. p. 943.

Kurrachee, February and May.

GeOMETRITES.

ENNomide.

98. Hyperythra swinhoei, Butler, Ann. \& Mag. Nat. Hist. ser. 5, vol. v. p. 223 (1880).

Kurrachee, May and November.

99. Hyperythra phantasma, Butler, P.Z. S. 1881, p. 615 .

Kurrachee, February.

\section{BOARMIIDE.}

100. Hypochroma PSeudo-terpnaria, Guénée, Phal. i.p. 276, n. 436 .

January and June.

101. Нypochroma dispensata, Walker, Cat. Lep. Het. B. M. xxi. p. 435.

January and June.

\section{Geometride.}

102. Nemoria Pruinosa, Butler, Ann. \& Mag. Nat. Hist. ser. 5, vol. v. p. 224 (1880).

January, May, September, and December. Very common.

103. Nemoria frequens, Butler, P.Z. S. 1881, p. 616.

April and November.

104. Thale ra diatomata, Walker, Cat. Lep. Het. B. M. xxvi. p. 1616.

November and December.

IDAIDE.

105. Idea distracta, Butler, P.Z.S. 1881, p. 616 .

Very common in May.

106. Idea remotata, Walker, Cat. Lep. Het. B. M. xxii. p. 748. Kurrachee, June.

107. Idea Jacta, n. sp. (Plate XLVIII. fig. 12.)

Kurrachee, May.

Pale pinkish white, irrorated with brown atoms; fore wings with 
the costa brownish ; a basal interrupted line, not reaching the costa, and very indistinct; antemedial, medial, and postmedial wavy lines brown; hind wings with only the medial and postmedial lines; fringe pure white. Expanse of wings $\frac{6}{10}$ inch.

108. Idea invalida, Butler, Ann. \& Mag. Nat. Hist. ser. 5, vol. v. p. 439 (1879).

Kurrachee, May and December.

109. Idea inductata, Walker, Cat. Lep. Het. B. M. xxiii. p. 792 .

Kurrachee, May, November, and December.

110. Idea actuaria, Walker, Cat. Lep. Het. B. M. xxiii. p. 752 .

Kurrachee, May.

\section{Fidonitide.}

111. Tephrina peremptaria, Walker, Cat. Lep. Het. B. M. xxiii. p. 929.

Kurrachee, November and December.

112. Tephrina lithina, Butler, P. Z. S. 1883, p. 171. January and March.

113. Tephrina arenaria, n. sp. (Plate XlViII. fig. 13.)

Kurrachee, December. Common.

Allied to T. arenaceara. Pale whitish bone-colour, slightly irrorated with brown atoms; costa thinly brown, a brown dot at the end of the cell : both wings with four faint brown lines:-1, interior and retracted towards the costa ; 2, medial ; 3 , exterior and double, and darker than the others; 4, marginal, slightly diffuse, with black points in the veins; there is also another shadowy line between the double and the marginal line, and which joins the double line at the costa; hind wing slightly angulated in the centre of the outer border. Expanse of wings $1 \frac{2}{10}$ inch.

114. Tephrina strenuataria, Walker, Cat. Lep. Het. B. M. xxvi. p. 1647.

May to July, November to December. Very common.

115. Fidonia albofascia, n. sp. (Plate XLViII. fig. 14.)

Kurrachee, September.

Body pale cinereous tinged with chocolate-brown ; antennæ moderately pectinated, except towards the tips; ground-colour of the wings whitish cinereous, basal third densely irrorated with chocolatebrown; a broad milk-white band across the centre of both wings, bordered on the inside by a chocolate-brown band, and on the outer side; the rest of the wing is coloured chocolate-brown, with the whitish ground-colour of the wing showing through here and there. Expanse of wings $\frac{9}{10}$ inch. 
116. Sterra Sacraria, Linn. Syst. Nat. i. (2) p. 863 (1766).

Common in November.

\section{Erosinde.}

117. Erosia hyperbolica, n. sp. (Plate XLVIII. fig. 15.)

Kurrachee, May.

General colour pale reddish cinereous; eyes black; body slender, cylindrical; fore wings with the costa straight, long, apex rounded, hinder margin very short, notched behind the angle, outer margin round, slightly toothed; hind wings small, with the outer margin produced into two long teeth. The entire surface of both wings deeply irrorated with reddish ochreous; a basal, medial, and outer band of dark reddish ochreous; a semidiaphanous white spot in the centre of the medial band of the fore wings; an elongated semidiaphanous latitudinal streak in the centre of the same band in the hind wings ; fringe whitish. Expanse of wings $1 \frac{2}{10}$ inch.

\section{CRAMBICES.}

\section{Crambide.}

118. Scirpophaga degenerella, Walker, Cat. Lep. Het. B. M. xxviii. p. 524.

Jemedar Ke Landi, March.

119. Crambus zonellus, n. sp. (Plate XlViII. fig. 16.)

Kurrachee, May.

Allied to C.decolorellus. Yellowish fawn-colour; abdomen whitish; last joint of the labial palpi very long, $\frac{1}{10}$ inch ; abdomen extending somewhat beyond the wings. Fore wings acute, outer border nearly straight, slightly oblique, marginal points black; fore wings darker towards the costa and outer border, a faint brown streak along the subcostal nervure, a black dot at the end of the cell, two brown spots below, on the submedian nervure, and a brown shadowy band running in from the apex, towards the centre of the hinder margin, but stopping half way ; hind wings whitish. Expanse of wings $\frac{8}{10}$ inch.

\section{NyCTEOLIDA.}

120. Earias tristrigosa, Butler, P. Z. S. 1881, p. 614.

Very common throughout the year.

121. Earias frondosana, Walker, Cat. Lep. Het. B. M. xxvii. p. 204.

Kurrachee, February.

TORTRICIDE.

122. Pedisca decolorana, Freyer, Neuere Beiträge, 318, 5 (1831-58).

February and May. 


\section{Phycide.}

123. Mella zinckenella, Treitschke, Schmett. Eur.ix.1. p. 20 (1832).

Very common in April and May.

124. Pempelia ilelda, n. sp. (Plate XLViII. fig. 6.)

Kurrachee, February, March, and May. Common.

Allied to $P$. cautella, from Ceylon. Fawn-colour; eyes black; thorax and fore wings clouded with brownish, fringe grey; abdomen paler ; hind wings pale greyish, semihyaline, with a brownish marginal line, fringe white. Expanse of wings $\frac{8}{10}$ inch.

\section{EXPLANATION OF THE PLATES.}

\section{Plate XlVII.}

Fig. 1. Phragmatrecia freda, n. sp., p. 515.

2. Zizera mora, n. sp., p. 506.

3. Terias curiosa, n. sp., p. 508.

4. Gomalia litoralis, n. sp., p. 513.

5. Orcesia vagabunda, n. sp., p. 519.

6. Caradrina sabulosa, n. sp., p. $5 \mathrm{i} 6$.

7. Acontia hortensis, n. sp., p. 517.

8. Erastria futilis, n. sp., p. 517.

9. Anthophila bulla, n. sp., p. 518.

10. Micra chalybea, n. sp., p. 518.

11. Orthosia infrequens, n. sp., p. 517.

12. Anthophila zamia, n. sp., p. 518.

13. Micra furia, n. sp., p. 519.

14. - balux, n. sp., p. 519.

15. Rivula flavonigra, n. sp., p. 522.

\section{Plate XLVIII.}

Fig. 1. Othora cenea, n. sp., p. 520.

2. Remigia arefacta, n. sp., p. 521 .

3. Pandesma devia, n. sp., p. 520.

4. Myana sopora, n. sp., p. 522 .

5. - atromacula, n. sp., p. 523.

6. Pempelia ilella, n. sp., p. 529.

7. Marimatha lactea, n. sp., p. 522.

8. Hypotia vafera, n sp., p. 523 .

9. 1 rubella, n. sp., p. 523.

10. Pyralis uberalis, n. sp., p. 523.

11. Scopula palmalis, n. sp., p. 525.

12. Idcea jacta, n. sp., p. 526.

13. Tephrina arenaria, n. sp., p. 527.

14. Fidonia albofascia, n. sp., p. 527.

15. Erosia hyperbolica, n. sp., p. 528.

16. Crambus zonellus, n. sp., p. 528 . 


\section{$2 \mathrm{BHL}$ Biodiversity Heritage Library}

Swinhoe, Charles. 1884. "On Lepidoptera collected at Kurrachee." Proceedings of the Zoological Society of London 1884, 503-529.

https://doi.org/10.1111/j.1096-3642.1884.tb02862.x.

View This Item Online: https://www.biodiversitylibrary.org/item/96832

DOI: https://doi.org/10.1111/j.1096-3642.1884.tb02862.x

Permalink: https://www.biodiversitylibrary.org/partpdf/73169

\section{Holding Institution}

Natural History Museum Library, London

\section{Sponsored by}

Natural History Museum Library, London

\section{Copyright \& Reuse}

Copyright Status: Public domain. The BHL considers that this work is no longer under copyright protection.

This document was created from content at the Biodiversity Heritage Library, the world's largest open access digital library for biodiversity literature and archives. Visit BHL at https://www.biodiversitylibrary.org. 